\title{
DETERMINANTS OF BUSINESS SUCCESS - THEORETICAL MODEL AND EMPIRICAL VERIFICATION
}

Robert Kozielski, Ph.D.

University of Lodz

Department of Marketing

Matejki 22/26; 90-237 Lódź, Poland

e-mail: rkozielski@post.pl

Received 13 June 2015, Accepted 11 June 2016

\begin{abstract}
Market knowledge, market orientation, learning competencies, and a business performance were the key issues of the research project conducted in the 2006 study. The main findings identified significant relationships between the independent variables (market knowledge, market orientation, learning competencies) and the dependent variables (business success). A partial correlation analysis indicated that a business success primarily relies on organisational learning competencies. Organisational learning competencies, to a large extent (almost $60 \%$ ), may be explained by the level of corporate market knowledge and market orientation. The aim of the paper is to evaluate to what extent the relationships between the variables are still valid. The research was based on primary and secondary data sources. The major field of the research was carried out in the form of quantitative studies. The results of the 2014 study are consistent with the previous (2006) results.
\end{abstract}

Keywords: business performance, strategy, learning organization, knowledge management, market orientation

JEL classification: M10 


\section{Introduction}

The issues of market measures (e.g. Harden, Heyman, 2011; Barwise, Farley, 2004; Ambler, 2003), market knowledge (McDonald, Madhavaram, 2007; Deshpande, 2001; Nonaka, 1994), market orientation (Kumar, Jones, Venkatesan, Leone, 2011; Day, 1990; Narver, Slater 1990; Kohli, Jaworski 1990) and organisational learning (Bernard, Osmonbekov, McKee, 2011; Cahill, 1995; Garvin, 1993; Schein, 1993) have been the subject matter of many publications. These questions have raised researchers' interest, both severally and jointly, and have been likewise examined and analysed. Also, attempts have been made to determine their impact on the organisation's market performance (Olavarietta, Driedmann, 2008; Haugland, Myrtveit, Nygaard, 2007; Slater, Narver, 1994; Greenley, 1995). Nevertheless, such analyses are nearly nonexistent in relation to Central and Eastern Europe.

In 2006, as a part of the Fulbright scholarship, a theoretical model was developed which took into account market metrics, knowledge, and market orientation as well as the organization's ability to learn as determinants of the market success of the organization. This model was a subject to empirical verification, e.g. the strength of relation among variables was determined and their influence on the market success of the organization was described (Kozielski, 2013). The aim of the current research project is to evaluate to what extent the relationships between variables are still valid.

\section{The Conceptual Model}

In this study, four independent variables have been taken into account - marketing metrics, market knowledge, marketing orientation, and organization's competency to learn. Based on the research, their relations with the dependent variable (business success) were examined. The concept and tools of marketing metrics are the key element of a marketing management process. A metric can be defined as a measuring system that quantifies a trend, dynamic, or characteristic (Farris et al., 2009). More generally, a metric is a measure of performance, and, in the context of marketing, it is a measure of marketing performance (CIM, 2014). Metrics are a fundamental component of a performance measurement system, which enables informed decisions to be made and actions to be taken, because it quantifies the efficiency and effectiveness of past actions through the acquisition, collation, sorting, analysis, and the interpretation of appropriate data (Neely et al., 2002). Marketing metrics and a performance measurement system are both input and basis for building organization's market knowledge. 
Market knowledge is becoming not only an asset, but also a source of competitive advantage. Polanyi has identified two kinds of knowledge (Polanyi, 1966). The first one is called explicit knowledge. Explicit knowledge refers to the knowledge that may be conveyed in a formal and systematic manner within the organisation (Nonaka, 1994), whereas the second kind of knowledge is tacit. This kind of knowledge is not easy to convey or communicate in a formal manner. It relates rather to an individual behaviour, activity, or commitment. Naturally, both kinds of knowledge are crucial for the organisation to build its competitive advantage. Taking into account the aim of this paper, following it should be noticed that market knowledge impacts on marketing orientation (Jaworski, Kohli, 1993) and learning organization (Day, 1994).

The significance of marketing orientation (Slater, Narver, 1995) and the concept of learning organisations (Garvin, 1993), and their influence on a corporate culture and performance generate volumes of literature. Nevertheless, it can be noted that many attempts to define both of these terms head in a similar direction, to the extent that some of the definitions for either of these notions are nearly identical. Organisational learning refers to a process of gaining, distributing, interpreting, and storing knowledge (Huber, 1991). From this perspective, marketing is attempted to be defined in a similar fashion. For instance, Kohli and Jaworski indicated three key components of marketing orientation - generating knowledge, disseminating knowledge,

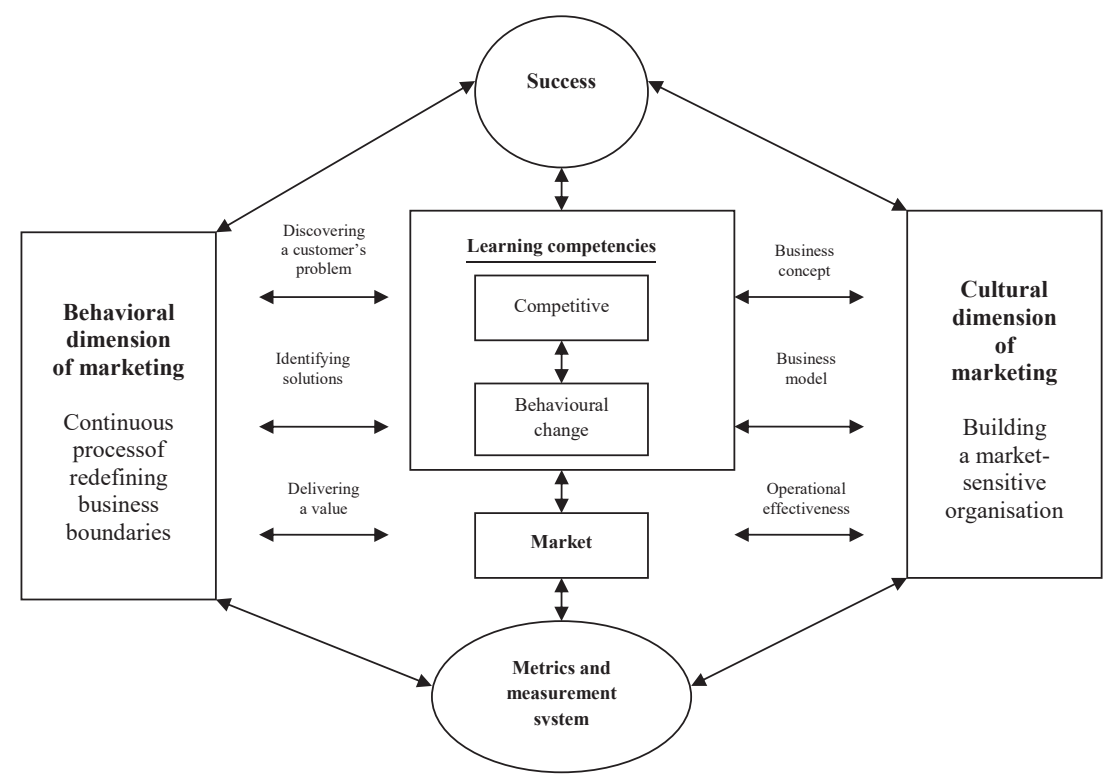

Figure 1. Marketing measurement and behavioral and cultural dimension of marketing Source: Kozielski (2013). 
and taking action on this basis (Kohli, Jaworski, 1990). Consequently, it has been noticed that marketing orientation and learning orientation are inextricably connected (Hurley, Hult, 1998), and that the marketing concept is an essential foundation of a learning an organisation's culture (Slater, Narver, 1995).

These variables along with business performance constitute the conceptual model in which marketing metrics deliver data and information, which are later transformed in order to create the market knowledge. Market knowledge, as mentioned before, is closely connected with marketing orientation and learning organization. The foregoing relations can be presented as in the diagram below.

\section{The 2006 study - research findings}

The main aim of the paper is to evaluate to what extent the relationships between variables are still valid. The starting point of the considerations should be based on the main conclusions derived from the research conducted in 2006. The first key notice refers to marketing metrics. Based on the existing state of knowledge, it was said that the number of applicable metrics did not play a decisive role (Kaplan, Norton, 1996). Were it otherwise, increasing the number of such metrics and their quality would lead to enhancing market performance. The companies which would apply more measurement parameters would be bound to accomplish better results. As yet, research findings have not confirmed this is the case (Abela, Clark, Ambler, 2004), therefore, marketing metrics (number and quality) were excluded from the previous and current analyses.

The 2006 study findings identified statistically significant relationships between independent variables (market knowledge, market orientation, learning competencies) and dependent variables (business success). These relations were also investigated with a partial correlation analysis, which allowed to discover slightly deeper findings. Business success primarily relies on organisational learning competencies. Organisational learning competencies, to a large extent (almost 60\%), may be explained by the level of corporate market knowledge and market orientation. It should be noted that the knowledge which, as has been found, should be treated as a strategic resource does not build competitive advantage.

Interestingly, market orientation was found to have no direct impact on business success. However, it was shown that market orientation has a significantly moderating role in the correlations between organisational learning competencies and market performance, and knowledge. In other words, the key axis of these correlations looks like there are metrics 
which build knowledge, knowledge affects organisational learning competencies, and, finally, organisational learning competencies have an impact on business performance. However, it is market orientation which plays a significant role. Knowledge is a strategic resource which may be used when the company has mastered the learning competencies, but it can fully affect corporate market performance when it serves to build market sensitivity and redefine business boundaries.

\section{Research Design}

Both, present (2014) and previous (2006), studies were conducted in a similar way. They employed two major data sources: secondary and primary. The secondary studies included basically literature studies and the findings available from some earlier research. The primary studies were, in nature, qualitative and quantitative research. The qualitative research was carried out at the preliminary stage of the research process, where the study project and measurement tools were subject to assessment by the experts - academics and practitioners. The purpose of this research was to obtain a preliminary diagnosis of the study subject, collect opinions on the study's objective and hypotheses, and then to initially verify the research tools. The research sample selection was, in nature, a judgmental selection, where the selection criteria included the company's size and market area.

The major field research was carried out in the form of quantitative studies. These were conducted in the form of direct interviews and questionnaire surveys (PAPI). They covered the correlations and interdependencies among a number of variables which should be measured in a way that would ensure reliable measurement readings. The key independent variables were: the number (NM) and quality of metrics (QM), market knowledge, market orientation, and organisational learning competencies. Market success was identified as a dependent variable.

The literature studies were the first step in the procedure of the development of measurement tools. Based on these, the selected variables identified those tools which had already been developed, published, and verified in the previous reference literature, e.g. market orientation (NarverI, Slater, 1990; Jaworski, Kohli, 1993), organisational learning competencies (Day, 1994), and market success (Balakrishnan, 1996; Ambler, Kokkinaki, 1997). For the outstanding variables (number and quality of indicators, market knowledge level), measurement tools were developed ad hoc. 
Reliability analyses were conducted for the identified variables. The scale of the values' reliability (coefficient alfa) is reported in Table 1. Relability for the majority of the selected items exceeds the requirements for exploratory research (Nunnally, 1978; Zaltman, Deshpande, 2001).

Table 1. Reliability analysis

\begin{tabular}{|l|c|c|}
\hline \multicolumn{1}{|c|}{ Item } & Cronbach Alfa -2006 & Cronbach Alfa -2014 \\
\hline Market Knowledge & 0.644 & 0.755 \\
\hline Market Orientation & 0.920 & 0.926 \\
\hline Learning Competencies & 0.909 & 0.901 \\
\hline Business Success & 0.939 & 0.938 \\
\hline
\end{tabular}

Source: primary study, Kozielski, 2006 and 2014.

\section{Analysis and results}

Taking into account the indicated aim of this paper, the results achieved in 2014 should be examined and compared along with the findings from 2006 in terms of three main perspectives:

- internal relationships between the independent variables - market knowledge, market orientation, learning competencies,

- relationships between independent (market knowledge, market orientation, learning competencies) and dependent variables (business success),

- key variables which influence business success.

Comparing the results achieved in 2006 (Table 2) with the 2014 studies (Table 3), it can be stated that there is a significant correlation between market knowledge, market orientation, and learning competencies, but they have different statistical power. The strongest relation was noticed between marketing orientation and learning competencies. This conclusion has appeared to be similar for both studies (2006 and 2014). However, in 2014 statistical power was of minor effect than in 2006. It was visible, in particular, in case of market knowledge and learning competencies. The statistical power of the relationship between marketing orientation and learning competencies is almost the same in 2014 study as it was in 2006 . That confirms the results found in 2006 study. 
Table 2. Correlation between market knowledge, market orientation, and learning competencies (the 2006 study)

\begin{tabular}{|c|c|c|c|}
\cline { 2 - 4 } \multicolumn{1}{l|}{} & Market knowledge & Market orientation & Learning competencies \\
\hline $\begin{array}{r}\text { Market knowledge } \\
\text { Pearson Correlation } \\
\text { Sig. }\end{array}$ & 1 & & \\
$\mathrm{~N}$ & & & \\
\hline Market orientation & & & \\
Pearson Correlation & 0.567 & & \\
Sig. & $\mathrm{p}<0.01$ & & 1 \\
$\mathrm{~N}$ & 188 & & \\
\hline Learning competencies rearson Correlation & 0.570 & 0.733 & \\
Sig. & $\mathrm{p}<0.01$ & $\mathrm{p}<0.01$ & \\
$\mathrm{~N}$ & 188 & 188 & \\
\hline
\end{tabular}

Source: primary study, Kozielski, 2006.

Table 3. Correlation between market knowledge, market orientation, and learning competencies (the 2014 study)

\begin{tabular}{|c|c|c|c|}
\hline & Market knowledge & Market orientation & Learning competencies \\
\hline \begin{tabular}{|r|} 
Market knowledge \\
Pearson Correlation \\
Sig. \\
$\mathrm{N}$
\end{tabular} & 1 & & \\
\hline \begin{tabular}{|r|} 
Market orientation \\
Pearson Correlation \\
Sig. \\
$\mathrm{N}$
\end{tabular} & $\begin{array}{c}0.359 \\
\mathrm{p}<0.01 \\
388\end{array}$ & 1 & \\
\hline \begin{tabular}{|r|} 
Learning competencies \\
Pearson Correlation \\
Sig. \\
$\mathrm{N}$
\end{tabular} & $\begin{array}{c}0.280 \\
\mathrm{p}<0.01 \\
388\end{array}$ & $\begin{array}{c}0.678 \\
\mathrm{p}<0.01 \\
388\end{array}$ & 1 \\
\hline
\end{tabular}

Source: primary study, Kozielski, 2014.

The second vital aspect of this analysis refers to the relation between business success and independent variables (market knowledge, market orientation, learning competencies). The results are presented in Table 4. Despite the fact that the results are in general similar, two main conclusions may be drawn. First - in the 2014 study, the statistical power of the relationships between business success and market orientation, and learning competencies are stronger than they were in the 2006 study. The relationship between business success and market knowledge has not been noticed. 
Table 4. Pearson Correlation Index for business success and independent variables

\begin{tabular}{|l|c|c|}
\cline { 2 - 3 } \multicolumn{1}{c|}{} & Business success & Business Success \\
\multicolumn{1}{c|}{} & 2006 & 2014 \\
\hline Market Knowledge & $0.22(\mathrm{p}<0.01)$ & $0.095($ non sign. $)$ \\
\hline Market Orientation & $0.24(\mathrm{p}<0.01)$ & $0.315(\mathrm{p}<0.01)$ \\
\hline Learning Competencies & $0.27(\mathrm{p}<0.01)$ & $0.311(\mathrm{p}<0.01)$ \\
\hline
\end{tabular}

Source: primary study, Kozielski, 2006 and 2014.

Similarly to the 2006 study, a partial correlation analysis among the variables was conducted. The results are presented in Table 5 and the main conclusions are as below:

- when market knowledge is under control, the level of market orientation and organisational learning competencies become weaker,

- when market orientation is under control, it clearly affects the correlations between the market knowledge and organisational learning competencies,

- when learning competency is the controlled variable, any correlations between the variables disappear.

The above findings are similar to those indicated in the 2006 study.

Table 5. Partial Correlation - Pearson Correlation index for business success and independent variables

\begin{tabular}{|c|c|c|c|c|}
\hline & Market knowledge & Market Orientation & $\begin{array}{c}\text { Learning } \\
\text { Competencies }\end{array}$ & $\begin{array}{c}\text { Business } \\
\text { Success }\end{array}$ \\
\hline \multicolumn{5}{|c|}{ Correlations } \\
\hline Market knowledge & 1 & & & \\
\hline Market Orientation & $0.57(0.36)$ & 1 & & \\
\hline Learning competencies & $0.57(0.28)$ & $0.73(0.68)$ & 1 & \\
\hline Business Success & $0.22(\mathrm{X})$ & $0.24(0.32)$ & $0.27(0.31)$ & 1 \\
\hline \multicolumn{5}{|c|}{ Controlling for market knowledge } \\
\hline \multicolumn{5}{|l|}{ Market knowledge } \\
\hline Market Orientation & & 1 & & \\
\hline Learning competencies & & $0.60(0.64)$ & 1 & \\
\hline Business Success & & $0.18(0.30)$ & $0.23(0.30)$ & 1 \\
\hline \multicolumn{5}{|c|}{ Controlling for market orientation } \\
\hline Market knowledge & 1 & & & \\
\hline \multicolumn{5}{|l|}{ Market Orientation } \\
\hline Learning competencies & $0.27(\mathrm{X})$ & & 1 & \\
\hline Business Success & $\mathrm{X}(\mathrm{X})$ & & $0.18(0.14)$ & 1 \\
\hline \multicolumn{5}{|c|}{ Controlling for learning competencies } \\
\hline Market knowledge & 1 & & & \\
\hline Market Orientation & $0.26(0.24)$ & 1 & & \\
\hline \multicolumn{5}{|l|}{ Learning competencies } \\
\hline Business Success & $\mathrm{X}(\mathrm{X})$ & $\mathrm{X}(\mathrm{X})$ & & 1 \\
\hline
\end{tabular}

Source: primary study, Kozielski, 2006 and 2014. 
To sum up, it can be said that the knowledge is an important, but not sufficient, element of building a successful business performance. Market orientation, if not correlated with corporate learning competencies, has no impact on a business performance. It is only organisational learning competencies that can directly affect a corporate business performance. In view of the foregoing, it can be attempted to describe organisational learning competencies through knowledge and market orientation. The regression model is presented below (Figure 2 for the 2006 study, and Figure 3 for the 2014 study).

\section{Model Summary}

\begin{tabular}{|c|c|c|c|c|}
\hline Model & $\mathrm{R}$ & R Square & $\begin{array}{c}\text { Adjusted R } \\
\text { Square }\end{array}$ & $\begin{array}{c}\text { Std. Error } \\
\text { of the Estimate }\end{array}$ \\
\hline 1 & $0.756^{a}$ & .572 & .567 & .75580 \\
\hline
\end{tabular}

\section{ANOVA}

\begin{tabular}{|ll|r|r|r|r|r|}
\hline \multicolumn{2}{|c|}{} & \multicolumn{1}{c|}{$\begin{array}{c}\text { Sum of } \\
\text { Squares }\end{array}$} & $\mathrm{df}$ & Mean Square & $\mathrm{F}$ & Sig. \\
\hline 1 & Regression & 141.124 & 2 & 70.562 & 123.524 & $.000^{\mathrm{a}}$ \\
& Residual & 105.679 & 185 & .571 & & \\
& Total & 246.803 & 187 & & & \\
\hline
\end{tabular}

a Predictors: (Constant), market orientation, market knowledge

b Dependent Variable: Learning competencies

\section{Coefficients $^{\mathrm{a}}$}

\begin{tabular}{|c|c|c|c|c|c|c|}
\hline \multirow{2}{*}{\multicolumn{2}{|c|}{ Model }} & \multicolumn{2}{|c|}{$\begin{array}{l}\text { Unstandardized } \\
\text { Coefficients }\end{array}$} & \multirow{2}{*}{$\begin{array}{l}\text { Standardized } \\
\text { Coefficients } \\
\text { Beta }\end{array}$} & \multirow[b]{2}{*}{$\mathrm{t}$} & \multirow[b]{2}{*}{ Sig. } \\
\hline & & B & Std. Error & & & \\
\hline & (Constant) & -1.611 & .574 & & -2.805 & .006 \\
\hline & Market knowledge & 1.050 & .270 & .227 & 3.888 & .000 \\
\hline & Market orientation & .663 & .064 & .604 & 10.336 & .000 \\
\hline
\end{tabular}

a Dependent Variable: Learning competencies

Figure 2. Learning competencies - regression model (2006 study)

Source: primary study, Kozielski, 2006.

The analysis presented above, to a very large extent, explicatesorganisational learning competencies. Also, it is statistically significant (ANOVA). It explains the variations of the variable it describes - organisational learning competencies - in as much as $57 \%$ (the 2006 study), and 46\% (the 2014 study). Both knowledge and market orientation have a statistically significant impact on the dependent variable. It can be stated that the study conducted in 2014 confirmed the results found during the 2006 research. 
Model Summary

\begin{tabular}{|l|c|r|r|rr|}
\hline Model & $\mathrm{R}$ & R Square & $\begin{array}{c}\text { Adjusted R } \\
\text { Square }\end{array}$ & \multicolumn{2}{|c|}{$\begin{array}{c}\text { Std. Error } \\
\text { of the Estimate }\end{array}$} \\
\hline 1 & $.679^{\mathrm{a}}$ & .461 & .458 & & .900 \\
\hline
\end{tabular}

a Predictors: (Constant), market orientation, market knowledge

ANOVA

\begin{tabular}{|ll|r|r|r|r|r|}
\hline \multicolumn{2}{|c|}{} & $\begin{array}{c}\text { Sum of } \\
\text { Squares }\end{array}$ & df & Mean Square & $\mathrm{F}$ & Sig. \\
\hline 1 & Regression & 266.410 & 2 & 133,205 & 164.530 & $.000^{\mathrm{a}}$ \\
& Residual & 311.700 & 385 & .810 & & \\
& Total & 578.111 & 387 & & & \\
\hline
\end{tabular}

a. Predictors: (Constant), market orientation, market knowledge

b. Dependent Variable: Learning competencies

Coefficients $^{a}$

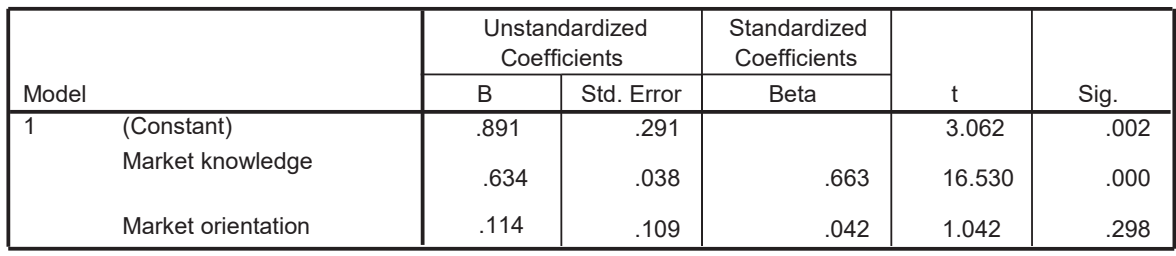

a. Dependent Variable: Learning competencies

Figure 3. Learning competencies - regression model (2014 study)

Source: primary study, Kozielski, 2014.

\section{Managerial implications and further research}

Based on the foregoing deliberations, it is possible to formulate a final comment and indicate directions for future research. The aim of the paper was to evaluate to what extent the relationships between the variables are still valid. Based on the current (the 2014 study) findings, it can be stated that the key conclusions drew in the 2006 study are still applicable. The significant internal relationships between the independent variables (market knowledge, market orientation, learning competencies) were observed. The relationships between the independent variables and dependent variable (business success) exist on the basic level, but a partial correlation analysis indicated that only learning competencies have a significant influence on business success.

Taking into account future studies, it can be useful to identify other variables, which impact on the business success. An in-depth study should be conducted to indicate the real role of marketing metrics, market knowledge, and marketing orientation in building a company 
success. Another vital issue refers to what extent business environment (macro and micro) modifies the results, and enforces changes in terms of the theoretical model. Unquestionably, the list of key questions can be easily expanded because the main challenge for both the researchers and managers is to explain the sources of a business success in the best possible way.

\section{References}

Abela, A.V., Clark, B.H., Ambler, T. (2004). Marketing Performance Measurement, Performance, and Learning. London: Workpaper.

Ambler, T. (2003). Marketing and the Bottom Line. London: Prentice Hall.

Ambler, T., Kokkinaki, F. (1997). Measures of Marketing Success. Journal of Marketing Management, 13 (7, October).

Balakrishnan, S. (1996). Benefits of Customer and Competitive Orientation in Industrial Markets. Industrial Marketing Management, 25 (4, July).

Barwise, P., Farley, J. (2004). Marketing Metrics - Status of Six Metrics in Five Countries. European Management Journal, 22 (3).

Bernard, E., Osmonbekov, T., McKee, D. (2011). Customer Learning Orientation in Public sector Organizations. Journal of Nonprofit \& Public Sector Marketing.

Cahill, D.J. (1995). The Managerial Implications of the Learning Organization - A New Tool for Internal Marketing. Journal of Services Marketing, 9 (4)

Day, G.S. (1994). Continuous Learning About Markets. California Management Review, Summer

Day, G.S., (1990). Market Driver Strategy - Process for Creating Value. New York: The Free Press.

Deshpande, R. (2001). Using market Knowledge. Thousand Oaks: Sage Publication Inc.

Farris, P.W., Bendle, N.T., Pfeifer, P.E., Reibstein, D.J. (2010). Key Marketing Metrics - the 50+ Metrics Every Manager Needs to Know. Harlow: Pearson.

Garvin, D.A. (1993). Building a Learning Organization. Harvard Business Review, July/August.

Greenley, G.E. (1995). Forms of Market Orientation in UK Companies. Journal of Management Studies, January $(32 / 1)$.

Harden, L, Heyman, B. (2011). Marketing by the Numbers. New York: Amacom.

Haugland, S.A., Myrtveit, I., Nygaard, A. (2007). Market Orientation and Performance in the Service Industry: A Data Envelopment Analysis. Journal of Business Research. 
Huber, G.P. (1991). Organizational Learning - The Contribution Processes and the Literatures. Organization Science, February.

Hurley, R.F., Hult, T. M. (1998). Innovation, Market Orientation, and Organizational Learning - An Integration and Empirical Examination. Journal of Marketing, July (62).

Jaworski, B.J., Kohli, A.K. (1993). Market Orientation - Antecedents and Consequences. Journal of Marketing, July (57).

Kaplan, R.S., Norton, D.P. (1996). Linking the Balanced Scorecard to Strategy. California Management Review, 39 (1), Fall.

Kohli, A.K., Jaworski, B.J. (1990). Market Orientation - The Construct, Research Propositions, and Managerial Implications. Journal of Marketing, April (54).

Kozielski, R. (2013). Marketing Metrics, Market Knowledge, Market Orientation, Learning Organization and Business Success in Emerging Countries - Theoretical Model and Empirical Verification. EBES Conference, Rome.

Kumar, V., Jones, E., Venkatesan, R., Leone, R.P. (2011). Is Market Orientation a Source of Sustainable Competitive Advantage or Simply a Cost of competing. Journal of Marketing, 75 (1).

Mastering Metrics (2014). London: CIM. The Chartered Institute of Marketing.

McDonald, R., Madhavaram, S. (2007). What Firm Learn Depends on What Firms Know: The Implications of Prior Knowledge for Market Orientation. Marketing Management Journal, Spring.

Narver, J.C., Slater, S.F. (1990). The Effect of Marketing Orientation on Business Profitability. Journal of Marketing, October (54).

Neely, A., Adams, Ch., Kennerley, M. (2002). The Performance Prism. London: Prentice Hall.

Nonaka, I. (1994). A Dynamic Theory of Organizational Knowledge Creation. Organization Science, February.

Nunnally, J.O. (1978). Psychometric Theory. New York: McGraw Hill.

Olavarietta, S., Driedmann, R. (2008). Market Orientation, Knowledge-Related Resources and Firm Performance. Journal of Business Research.

Schein, E.H. (1993). How Can Organizations Learn Faster? The Challenge of Entering the Green Room. Sloan Management Review, Winter.

Slater, S.F., Narver, J.C. (1994). Does Competitive Environment Moderate the Market Orientation-Perfomance Relationship. Journal of Marketing, January (58).

Slater, S.F., Narver, J.C. (1995). Market Orientation and Learning Organization. Journal of Marketing, July (59).

Zaltman, G., Deshpande, R. (2001). The Use of Market Research. In: R. Desphpande (ed.), Using Market Knowledge. Thousand Oaks: MSI, Sage Pabilications. 